\title{
The Third International Congress of Entomology.
}

THE third International Congress of Entomology, held at Zurich on July I9-26, was attended by about 200 representative entomologists and about 50 guests including 40 ladies. The Congress proved a great success. More nations were represented than at Brussels or Oxford, and it was a matter of regret that France, Italy and Belgium were not officially represented. One is glad to add, however, that the rate of exchange unfavourable to these countries was a contributory cause to the absence of men who will be welcomed at the next conference three years hence. During the Congress, members had opportunity of examining the fine collections in the adjoining Entomological Institute and the University Zoological Museum, as also the collection of Prof. Standfuss and the palæarctic collection of Dr. Corti. The Concilium Bibliographicum also received its quota of admiring visitors.

The town of Zurich itself, in the fine weather of the week, with its famed Lake, received the usual meed of praise, and especially it showed to great advantage as it was viewed during the ascent of the Uetliberg by funicular railway on one of the Congress excursions; while in the descent in the dark, the lights of the numerous buildings dotted all over the hillside suggested so many majestic glow-worms.

The Congress was opened by Dr. A. von Schulthess, its popular president, who took occasion to emphasise the successes of the early Swiss entomologists. $\mathrm{He}$ was followed by the Rector of the University, Prof. Dr. Bleuler, who gave the delegates a cordial welcome on behalf of the Canton of Zurich and of the University. Dr. Bleuler, besides emphasising the great importance of insects in the spread of various diseases, referred to the psychic problems underlying insect life and habits, a branch of the subject to which Swiss entomologists have made valuable contributions.

The forenoons were devoted to general meetings, the afternoons to sectional ones. It is impossible to name all the papers presented as this summary can only be a general one. As regards the forenoon meetings, Dr. F. Ris (Switzerland) read an interesting paper on the geographical distribution of insects in Switzerland, dealing first of all with the effects of glacial times, when Switzerland was covered with ice, and going on to quote examples of the influence of man on the relationship between animals and plants. Prof. Leiper, of the London School of Tropical Medicine, spoke on "Some Outstanding Questions in Medical Entomology." He quoted instances of the already proved relationship between diseases due to protozoa and worms conveyed by insects or arachnids, and named numerous other important diseases in which a "vector" insect or arachnid host might be justly suspected. More accurate knowledge regarding these is greatly desired, and a strong plea was made for the co-operation of the parasitologist and the economic entomologist.

The fascinating subject of mimicry never fails to attract a large audience. As regards the explanation of specific instances-teleological, physiological, chemical, mechanical, and so on-one can only say "Tot homines quot sententic." On the present occasion, Prof. E. B. Poulton, of Oxford, who has done so much for the success of the three International Congresses, and Prof. van Bemmelen, of Holland, were the protagonists. The debate between these two experts was a model of how such a controversy should be conducted. Their mode of presentation of the subject, and their manner of differing, won the listener, who was tempted to throw logic to the winds and wish or even declare that the debaters were both right, as of course up to a point both were. Prof. Poulton illustrated, by means of coloured figures and actual specimens, mimicry in African butterflies of the nymphaline genus Charaxes, and pointed out new aspects of the subject. The genus Charaxes is one of powerful fliers and yet there is much mimetic association. They often mimic each other in pattern, as is most evident in the females of the smaller species, which resemble the males as well as the females of larger species. Dr. Richard van Someren has proved by breeding from known female parents that three of these mimics in Uganda, although totally different in appearance, are the females of the same species. Mr. C. F. M. Swynnerton has shown that the quality mimicked in this case is the quality of " fighting weight " and toughness, rendering the butterflies, and especially the larger species, very difficult to hold and reduce to a condition in which they can be comfortably swallowed. Prof. van Bemmelen argued that different mimetic patterns are derived from a common ancestral pattern and need not imply any mimetic association.

At another meeting mimicry was brought up again by the veteran Father Wasmann, in his address on the staphylinids which live in happyassociation with certain ants. This was only one of several weighty pronouncements from Father Wasmann, as, for example, his contribution to the discussion on Dr. H. Eidmann's paper on "The Foundation of Colonies in Ants." Setting aside the foundation of a new colony by secession, there are two principal types of sexual reproduction of an ant colony. One is the independent or autonomic colony foundation where the fertilised female is able to found a colony by herself and without any aid. In the other case the female requires, for rearing her young larvæ, the help of other ants. One type of these is the red slaveworking ant Formica sanguinea, which lives in mixed colonies with workers of Formica fusca. Eidmann isolated a fertilised queen of $F$. sanguinea and after a fortnight put her into an artificial nest consisting of some twenty workers and one hundred cocoons of $F$. fusca. The introduced queen attacked the workers, killed one after the other in severe fight, and took possession of the cocoons. She looked after the cocoons and in a short time had a little troop of newly issued slave ants to help her to rear her eggs and larvæ.

Mr. F. Balfour Browne, of Cambridge, spoke on "The Evolution of Social Life among Caterpillars," basing his argument on a number of illustrated cases chosen from the Lepidoptera, beginning with the silk-spinning habit as protective and going on to feeding nest or web, and then to home nests. C. B. Williams, of Egypt, spoke on "Some Unsolved Problems of Butterfly Migration," quoting interesting examples and inviting co-operation and exact observation.

Instructive papers on the history and progress of the study of entomology in different countries, in its various branches, were given by Escherich for Germany, Tragardh for Sweden, Mokozecki for Poland, Fletcher for India, and Urich for the West Indies.

As regards the sectional meetings, many valuable papers were read, and it may safely be hazarded that the volume of the Proceedings of the Congress will be found very helpful to entomological workers all over the world. It is impossible in this summary to mention all the individual papers. The sections were: (I) Morphology, Anatomy and Physiology ; (2) Systematic and Geographical Distribution; (3) Nomenclature and Bibliography; (4) Biology and Development ; (5) Applied Entomology ; and it must 
suffice to say that there was no lack of material or of discussion. As the various sections met at the same hour, it was not easy always to decide which paper to miss, so that with a choice of good things one often wished, like Boyle Roche's bird, to be in two places at the same time. Of such papers as I managed to hear myself, I may mention Horn of Berlin on systematic entomology, Edwards on the phylogeny of nematocerous Diptera, the Aphid papers of Börner, Davidson and Munro, Pictet on parthenogenesis, Prell on Polyeder diseases of insects, Brun on the anatomy of the brain, and Jablonowski's papers in the Economic Section. To listen to Jablonowski " annihilating time and tearing a passion to tatters" was one of the treats of the Congress. The wide appeal of the Congress will be gauged if in addition to the names already given I mention Handlirsch of Vienna, whom one was glad to see taking an active part again, Nuttall and Scott of Cambridge, Ettringham of Oxford, Carlier of Birmingham, Heymons, Schwartz and Schuberg of Berlin, Eckstein of Eberswalde, Reh of Hamburg, Everts of Holland, Johannsen of the United States, Lord Rothschild and Jordan of Tring (the Congress owed much to Jordan's organisation and committee work), Marshall and Neave of the Imperial Bureau of Entomology, Waterston and a worthy representation from the British Museum, Blendowski of Poland, Rennie from Scotland, Turati from Italy, Kryger from Denmark, and Monzen of Japan, and a naturally large representation of well-known Swiss entomologists. A special tribute must be paid to Dr. L. O. Howard, of the United States Department of Entomology. Always in a position to help and using his position to help, Dr. Howard has earned the gratitude of entomologists everywhere. Capable and kindly, always with the right word, and with tact as his middle name, Howard gives one the feeling that were there a dozen representative ambassadors like him in the political world, we would soon have, what some of us long for, the United States of Europe, each nation no longer at enmity with the other but working out its own salvation following the lines of its own culture and psychology. Certainly there was a spirit of friendliness and goodwill at the Congress, attesting that science has no limited boundaries but is international.

Much hard committee work was done during the week, and the Section on Entomological Nomenclature has so co-ordinated opinions from various sources that hopes are high for general agreement.
The nomenclature question is in some ways an appalling one to tackle, and it is surprising the amount of time and labour expended in trying to reach an international system that would be clear and consistent.

The position of systematic entomology and the status of the systematist in university and museum were also subjects of committee work, and the Congress passed resolutions that are satisfying. In the economic sections also, attention has been focussed on the need for a recognition of the deeper problems underlying entomological research, and the Congress passed the following resolution: "The Congress considers it essential that the problems underlying Applied Entomology should be studied and desires to impress upon Governments and Institutions concerned with investigations in Applied Entomology that time must be devoted to Systematic Entomology and fundamental research, such as Insect Physiology, Ecology and Pathology, since only by the study of these can insect control be placed on a sound basis."

This report is already long else one would have liked to mention some of the more humorous features of the week's meeting. Only one can be mentioned. A steamer heavily laden with the members of the Congress, in a sail round Lake Zurich, reached a certain little town at dinner-time. "The Assyrians came down like a wolf on the fold," or, entomologically, the locusts swarmed ashore to find that the village Chief of the Commissariat had blundered and food failed. But this was a meeting of biologists, and soon was seen in practice Natural Selection working through the struggle for existence and the survival of the fittest-the badge of the fit taking the guise of half a sausage. Whether the raiding habits developed in the struggle will become an acquired character time alone can show. One is glad to add, however, that as opposed to "Nature red in tooth and claw" the co-operative and ethical aspect of the struggle for existence received due iliustration.

On the evening preceding the close of the Congress a banquet was held and every one enjoyed the night's social leisure. On the last day of the Congress two papers were read and the Congress then resolved itself into a Business Meeting. The president was heartily congratulated on a highly successful meeting.

Several extra excursions were arranged to follow the close of the Congress, e.g. to the Rigi Summit and the Jung Frau. R. Stewart MacDougall.

\section{Lathyrism.}

$\mathrm{F}$ the chronic diseases which are directly related to the food supply and only indirectly connected with the presence of infective agents, most attention has in recent years been paid to that group in which the symptoms are due to the deficiency of some element in the diet, more especially that of one of the vitamins ; scurvy, beri-beri, and probably rickets are among the diseases in this class. The other group, of which ergotism is the best known example, is due to the presence in the food consumed of small quantities of some poison, which after prolonged administration affects various organs of the body with the production of symptoms. The chronicity of the disease distinguishes this group from cases of acute poisoning due to bacterial products taken with the food or to the ingestion of some well-known poisonous substance.

The occurrence of lathyrism, which has been met with in India and in countries bordering on the Mediterranean, has been for long ascribed to the consumption of the seeds of pulses of the genus Lathyrus. In India the seeds of Lathyrus sativus, known in the vernacular as khesari, occupy a large place in the diet in certain districts, in which also a form of paralysis is frequently seen, especially among those who utilise the pulse as the staple article of their diet. L. A. P. Anderson, A. Howard, and J. L. Simonsen (Indian Journ. Med. Research, 1925, vol. I2, p. 613) have recently conducted an investigation into this disease, from the results of which certain important conclusions can be drawn. At the outset of their work, the investigators recognised that the crop of Lathyrus sativus is scarcely ever grown in pure culture, but is frequently contaminated with various weeds; the seeds of one of these, the vetch Vicia sativa, L. var. angustifolia, were present in every sample of khesari obtained from districts in which lathyrism is common; attention was thus attracted especially to this weed, which is known in the vernacular as akta. As the result of both chemical analysis and feeding experiments with ducks and monkeys, the important conclusion was reached that pure khesari seeds contain no alkaloids; in fact they form a nourishing diet for these animals.

Quite different results were obtained with the seeds

NO. $291 \mathrm{I}$, VOL II6] 